Paweł Płoski (iD) https://orcid.org/0000-0001-7608-2856

Akademia Teatralna im. Aleksandra Zelwerowicza w Warszawie e-mail: pawel.ploski@e-at.edu.pl

Otrzymano/Received: 5.01 .2020

Zaakceptowano/Accepted: 11.02.2020

Opublikowano/Published: 31.03.2020

\title{
Epizod konstruktywny. Fundusz Rozwoju Kultury $1983-1990^{1}$
}

$\mid$

\section{Abstract \\ Constructive Episode. The Culture Development Fund 1983-1990}

The main goal of the article is to present the first comprehensive and universal mechanism of financing of culture in Poland - state-earmarked fund, the Culture Development Fund. I present the circumstances of the birth of the idea, the creation and functioning of the Fund. This is one of the most interesting examples of cultural policy reforms in Poland - in the article I present the pros and cons of this solution. This text is part of institutional research on the organization and financing of theater in the People's Republic of Poland.

Keywords: cultural policy, Polish People’s Republic, mechanisms for financing culture, institutional analysis

Słowa kluczowe: polityka kulturalna, Polska Rzeczpospolita Ludowa, mechanizmy finansowania kultury, analiza instytucjonalna

1 Artykuł napisany w ramach realizacji stypendium Ministra Kultury i Dziedzictwa Narodowego. 


\section{Wprowadzenie}

W opisach funkcjonowania życia kulturalnego w Polskiej Rzeczpospolitej Ludowej sprawy organizacji czy finansowania są traktowane jako kwestie niemal przezroczyste. Można odnieść wrażenie, że system stworzony pod koniec lat czterdziestych XX wieku, w czasach stalinizmu, trwał bez większych zmian i zakłóceń niemal po rok 1989, a właściwie jedynym jego zadaniem było poszerzanie sfery wolności. Po bliższym przyjrzeniu się obraz się komplikuje - docieramy do śladów licznych dyskusji, do zapomnianych projektów reform, a także do inicjatyw zrealizowanych z większym czy mniejszym powodzeniem.

Celem artykułu jest przypomnienie jednego z ciekawszych przykładów reformy funkcjonowania kultury w socjalistycznej Polsce - powstania i działania Funduszu Rozwoju Kultury. Chcę pokazać, że rozwiązanie zastosowane w ostatniej dekadzie PRL z jednej strony stało się sposobem na wyjście sfery kultury z kryzysu, z drugiej zaś strony było inspirującym przykładem efektywnego narzędzia finansowania kultury - całościowego i powszechnego mechanizmu pozabudżetowego.

W pierwszej części zwracam uwagę na źródła tej koncepcji, które mają swój początek w pracach nad reformą gospodarczą PRL. W kolejnych częściach opisuję powstanie oraz funkcjonowanie Funduszu. Artykuł kończy część poświęcona likwidacji samego Funduszu oraz sposobom kontynuowania tego mechanizmu. (W tekście pomijam Narodową Radę Kultury - utworzoną razem z Funduszem, wspominam o niej, o ile miała związek z FRK).

Polityka kulturalna PRL nie doczekała się jeszcze pełnego opracowania. Właściwie tylko losy kinematografii zostały gruntownie i całościowo przebadane $\mathrm{w}$ aspekcie organizacji i finansowania w czasach PRL [Zajiček 2009]. Odnotować należy publikację dotyczącą dekady lat siedemdziesiątych [Szczutkowska 2014]. W przypadku teatru są znakomite prace opisujące pierwsze lata - okres stalinizmu [Jarmułowicz 2003] oraz Październik 1956 [Napiontkowa 2012]. W wypadku sztuk wizualnych to opracowania problemowe poświecone instytucji galerii [Lachowski 2006] czy mecenatu przemysłowego nad sztuką [Stano 2019]. Jednakże schyłek PRL, szczególnie lata osiemdziesiąte, nie stały się jeszcze przedmiotem gruntownych analiz. Można mówić o wzmiankach przy okazji opisu szerszych zagadnień - jak w wypadku opisania „kieszonkowej rewolucji kulturalnej” po roku 1986 [Kowal 2012]. Właściwie dysponujemy tylko opracowaniami z tamtych czasów, które stanowią jednocześnie źródło cennych i rozproszonych informacji. Autorów tych prac przywołam w kolejnych częściach tego artykułu.

Niniejszy tekst, inspirowany metodami z kręgu szeroko rozumianego nowego instytucjonalizmu, jest rezultatem moich badań dotyczących organizacji i finansowania teatru w PRL. W pracy korzystałem z metody analizy źródeł historycznych oraz metody analizy instytucjonalnej. Opisanie Funduszu Rozwoju Kultury pozwala uzupełnić naszą wiedzę o mechanizmach polityki kulturalnej w Polsce Ludowej. 
Dodatkowym celem tego tekstu jest ukazanie tła historycznego współczesnej kultury polskiej oraz opisanie procesów podejmowania decyzji - pokazanie na konkretnych przykładach praktyki zarządczej i instytucjonalnej ówczesnych decydentów.

\section{Kultura i pierwszy etap reformy gospodarczej}

Po Porozumieniach Sierpniowych także w dziedzinie polityki kulturalnej zaczęły się zmiany, będące konsekwencją działań nowego - niezależnego i samorządnego związku zawodowego.

W listopadzie 1980 roku w czasie strajku „Solidarności” pracowników kultury w Urzędzie Wojewódzkim w Gdańsku głównym postulatem było zwiększenie nakładów na kulturę do 2\% dochodu narodowego [Rosenberg 2016: 215]. Komisja z Ministerstwa Kultury i Sztuki uznała ten postulat za słuszny - niemniej miała pełnomocnictwa, by w imieniu rządu zobowiązać się do wzrostu nakładów finansowych na kulturę na rok 1981, ale jedynie do wysokości 0,6\% dochodu narodowego do podziału „oraz do przedstawienia przez rząd w planie 5-letnim corocznego wzrostu udziału w dochodzie narodowym do $1,1 \%$ do roku 1985. Oznaczałoby to $2 \%$ w budżecie państwa wg poziomu roku 1980" [Protokół porozumienia... 1980]. Uzgodniono, że nakłady w 1981 roku wyniosą 0,9\% budżetu państwa (ostatecznie zrealizowano zaplanowane przez rząd wydatki w wysokości 0,6\%).

$\mathrm{Na}$ ogół jednak nie pamięta się, że Karnawał „Solidarności” był momentem dramatycznego załamania finansowania kultury. Pracownicy przedsiębiorstw produkcyjnych upomnieli się o prawo do korzystania w pełnym wymiarze $\mathrm{z}$ funduszy socjalnych zakładów pracy i związków zawodowych - sprzeciwili się dalszemu finansowaniu działalności kulturalnej.

Bowiem przez wiele lat istotnym źródłem dodatkowych środków na kulturę w PRL były zakłady pracy i związki zawodowe. W latach siedemdziesiątych w skali kraju środki na kulturę pochodziły z trzech podstawowych źródeł: 35\% pokrywał budżet centralny, $40 \%$ - budżet terenowy, 25\% - budżety związków zawodowych i innych organizacji [Wallis 1981: 87]. W samych instytucjach z budżetu państwa [na poziomie centralnym i terenowym] pochodziło około $60 \%$ środków finansowych. Środki „przekazywane przez ludność” (czyli sprzedaż biletów itp.) stanowiły około 25\%, a przez zakłady pracy - około 15\% [Strąk 1983: 249].

Po sierpniu związkowcy z „Solidarności” zakwestionowali sens finansowania zakładowych domów kultury, zakupów biletów do teatrów i filharmonii z funduszy socjalnych. Jednocześnie początek reformy gospodarczej i nowa ustawa o przedsiębiorstwach państwowych wprost prowadziły do likwidacji takich „elementów nadbudowy", dodatkowych kosztów.

Nagły brak - w roku 1981 - tych 15\% oznaczał dla części instytucji dziurę w budżecie. Natomiast dla wielu zakładowych bibliotek czy domów kultury - widmo 
likwidacji. Groźba ta dotyczyła nie tylko instytucji kulturalnych, ale także obiektów sportowych czy zakładowych żłobków.

W trybie nagłym w kwietniu 1981 roku znowelizowano Rozporządzenie w sprawie zakładowego funduszu socjalnego i zakładowej działalności socjalnej [Rozporządzenie Rady Ministrów z dnia 2 listopada 1973...], by umożliwić terenowym organom administracji państwowej przejmowanie tego typu jednostek - na wniosek zakładów [Żuber 1990: 19-20]. Choć też trzeba przyznać, że władze wykorzystywały ten temat - był to kolejny znakomity dowód destrukcyjnego wpływu „Solidarności” na społeczeństwo. Dlatego Komisja Kultury NSZZ „Solidarność” Regionu Mazowsze, a szczególnie jej „podkomisja kultury czynnej” - w której działali między innymi Elżbieta Matynia, Wojciech Krukowski, Konstanty Puzyna, Lech Śliwonik - intensywnie broniła istnienia tych placówek, „bo państwo na złość Solidarności chciało je zniszczyć" [Śliwonik, Uniejewska 2014].

Powyższe batalie odbywały się w kontekście prac nad generalną reformą gospodarki. Polski rząd chciał między innymi skorzystać z doświadczeń węgierskich, gdzie "gulaszowy socjalizm” opierał się na (w miarę racjonalnym) rachunku ekonomicznym. I z trudem wprowadzał podobne rozwiązania w PRL.

Na początku 1981 roku powstała, powołana przez rząd, Komisja ds. Reformy Gospodarczej, której zadaniem było przygotowanie nowego modelu funkcjonowania polskiej gospodarki - tworzyć ją miały rentowne przedsiębiorstwa państwowe. W połowie roku 1981 Komisja wypracowała dokument Kierunki reformy gospodarczej, godzący zwolenników systemu nakazowego ze zwolennikami redukcji roli państwa. Pierwszym elementem reformy była uchwalona ustawa o przedsiębiorstwach państwowych [Ustawa $\mathrm{z}$ dnia 26 września 1981 r. o przedsiębiorstwach...] oraz o samorządzie załogi przedsiębiorstwa państwowego. Zarządzanie przedsiębiorstwami w gospodarce socjalistycznej miało się odbywać zgodnie z zasadą trzech „S”: samodzielność, samorządność i samofinansowanie.

Kilka miesięcy później, już w zupełnie odmiennej sytuacji politycznej, 26 lutego 1982 roku, Sejm uchwalił pakiet ustaw gospodarczych, między innymi ustawę o planowaniu społeczno-gospodarczym, o cenach (urzędowych, regulowanych i umownych), o gospodarce finansowej przedsiębiorstw państwowych, o opodatkowaniu przedsiębiorstw państwowych, o prawie bankowym, o uprawnieniach do prowadzenia handlu zagranicznego. Na krótko widziano w tym aspekty wolnorynkowe. Jerzy Waldorff na posiedzeniu sejmowej Komisji Kultury i Sztuki w czerwcu 1982 roku zwracał uwagę na złe tendencje, które się wówczas ujawniły:

Podstawowy warunek reformy tzw. trzy „S” dały już o sobie znać w Polskich Nagraniach, kiedy to odmówiono nagrania dzieł Szymanowskiego, bo jest to nieopłacalne, chętnie natomiast podejmowane są opłacalne nagrania piosenek Maryli Rodowicz czy Andrzeja Rosiewicza. Musimy radykalnie zapobiec takim zjawiskom, gdyż inaczej dojdzie do tego, że Teatr Wielki nie będzie spełniał swego podstawowego zadania, a będziemy musieli zamienić go na małe 
loże z kurtynkami, które będą służyć do innych celów - bardziej opłacalnych [BPS/585/VIII kad. z 23 czerwca 1982: 12].

Ostatecznie pierwszy etap reformy gospodarczej został spowolniony i wreszcie zatrzymany przez niekończące się spory i gry grup interesów. Oficjalnie reformę popierano, niemniej jednak w poufnych rozmowach na szczytach władzy nie kryto dystansu. Premier Zbigniew Messner uważał, że doprowadzenie reformy do końca oznaczać będzie zmianę ustroju społeczno-gospodarczego [Dudek 2004: 30]. W samych przedsiębiorstwach dawały o sobie znać „stare nawyki aparatu gospodarczego, z reguły biernie oczekującego instrukcji z góry i przywiązanego do centralistycznych metod zarządzania" [Sowa 2011: 521]. Jak zauważa Adam Leszczyński, problemy gospodarki socjalistycznej miały charakter instytucjonalny i polityczny: „Stalinizm stworzył aparat władzy, którego interesy w praktyce zawsze górowały nad potrzebą reformy gospodarczej" [Leszczyński 2013: 349]. Tak było w latach pięćdziesiątych, tak było i w latach osiemdziesiątych. Nie można zatem dziwić się słowom wicepremiera Zbigniewa Szałajdy, który odnosząc się do protestów dyrektorów przedsiębiorstw skarżących się na ręczne sterowanie gospodarką pomimo reformy, zapytał: „Czy tę samodzielność chcecie bez dotacji?" [Dudek 2004: 33].

Nowe przepisy stworzyły sytuację, która zagroziła funkcjonowaniu nierentownych przedsiębiorstw państwowych, wśród nich były też przedsiębiorstwa widowiskowe - teatry, opery, filharmonie.

Szczególnie dotkliwe okazały się nowe regulacje dotyczące płac, utrudniające podwyżki, na przykład odpis na Państwowy Fundusz Aktywizacji Zawodowej (PFAZ) liczony od wypracowanego zysku. W wypadku teatru jako zysk traktowano... dotację. Dodatkowo odpisem na PFAZ obciążano fundusz honorariów - nie biorąc pod uwagę tego, że w teatrach czy filharmoniach fundusz ten nie był związany ze stałym zatrudnieniem, a pozwalał angażować dyrygentów, reżyserów czy scenografów [Bieniewski 1987: 153]. Ostatecznie nawet w deficytowej gospodarce przedsiębiorstw widowiskowych odpisy na PFAZ urastały do astronomicznych kwot. Po 1982 roku w jednym ze stołecznych teatrów podatek wyniósł $60 \mathrm{mln}$ zł, a dotacja dla tej sceny sięgnęła kwoty $69 \mathrm{mln}$ zł. Oczywiście kłopot rozwiązywano za pomocą umorzeń. Problemy instytucji kulturalnych potęgowała wspominana już rezygnacja $\mathrm{z}$ finansowania kultury przez związki zawodowe czy fundusze socjalne przedsiębiorstw.

W momencie gdy powstała już podstawowa koncepcja reformy, w czerwcu 1981 roku powołano Zespół XIII Komisji - Zespół ds. Usług Społecznych, któremu przewodniczył prof. Aleksander Łukaszewicz, ekonomista, wykładowca Uniwersytetu Warszawskiego, ekspert w zakresie planowania gospodarczego. Przedmiotem prac zespołu było wypracowanie koncepcji dostosowania poszczególnych dziedzin kultury do nowej sytuacji w gospodarce. W zespole wyodrębniono podzespoły opracowujące program dla odpowiednich dziedzin usług społecznych: zdrowia, oświaty, kultury, nauki i szkolnictwa wyższego, turystyki, sportu i kultury fizycznej. W pracach 
podzespołu ds. kultury uczestniczyli między innymi: politolog Michał Strąk jako przewodniczący, ekonomiści Stanisława Golinowska, Władysław Dawidowicz, Józef Mąka, socjolog Jerzy Kossak i przedstawiciele branż, na przykład Stanisław Bębenek (prezes „Czytelnika”) czy Andrzej Jarecki i Stanisław Piotrowski (reprezentujący teatr) [Strąk oprac. 1984: 64-65]. Jednocześnie trwały prace w grupach zajmujących się kinematografią, wydawnictwami, domami kultury, wsią czy instytucjami artystycznymi - w tym przypadku inicjatorem działań był Departament Teatru MKiS.

Najpierw podzespół opracował ocenę stanu instytucji kulturalnych przed uruchomieniem reformy. Wniosek podstawowy: na rozwój kultury przeznaczano z budżetu państwa zbyt małą ilość środków, które dzielono między instytucje bez brania pod uwagę intensywności i jakości ich pracy. Systemy organizacyjne i ekonomiczne, w ramach których prowadzono działalność kulturalną, nie uwzględniały jej specyfiki - instytucje kulturalne opierały swą pracę na regułach wypracowanych dla wszystkich przedsiębiorstw, co nakładało na nie liczne nieracjonalne ograniczenia. $\mathrm{W}$ opinii podzespołu brakowało wiele usprawniających pracę przedsiębiorstw widowiskowych mechanizmów, na przykład takiego, który wiązałby ceny ze wzrostem kosztów i rosnącą zamożnością społeczeństwa, albo takiego, który poziom nakładów inwestycyjnych i poziom płac w sferze kultury związałby z poziomem tych wskaźników w całej gospodarce. W wypadku teatrów czy filharmonii system nie wymuszał wysokiego poziomu artystycznego ich działalności: brakowało „rozwiązań uzależniających sytuację materialną instytucji i pracowników od walorów artystycznych ich produkcji" [Strąk oprac. 1984: 67].

Niezależnie od tych nieco racjonalnych (jeszcze nie wolnorynkowych) wniosków dotyczących efektywności finansowania polskiej kultury głównym celem prac zespołu było niedopuszczenie do sytuacji, w której przedsiębiorstwa artystyczne zaczęłyby obowiązywać coraz bardziej restrykcyjne reguły wynikające z reformy gospodarczej, wymuszające lepsze zarządzanie zwykłymi przedsiębiorstwami produkcyjnymi. Ponadto należało: zapewnić stabilny dopływ środków, zwiększyć racjonalność wydatków oraz wpływ środowisk i odbiorców kultury na politykę kulturalną. Warunkiem powodzenia było przygotowanie podstaw prawnych tego procesu: uspołecznienie formułowania i realizacji polityki kulturalnej, umocnienie pozycji ministra kultury i sztuki, określenie nowego źródła finansowania kultury ze środków państwa i przedsiębiorstw oraz nowych zasad finansowania instytucji kultury. Jednocześnie jasne było, że zmiany muszą chronić kulturę, która nie wypracowuje dochodu: „Jeśli w sferze produkcji materialnej pytamy przede wszystkim o to, czy dotować, to w kulturze w centrum uwagi staje kwestia, jak dotować?” [Strąk oprac. 1984: 68]. 


\section{Narodziny pomyslu}

Wobec załamania finansowania działalności kulturalnej z funduszy zakładowych i związkowych pospiesznie szukano nowych rozwiązań, które pozwoliłyby zyskać dodatkowe środki. W połowie roku $1981 \mathrm{w}$ trakcie dyskusji pojawił się pomysł pozabudżetowego narzędzia - funduszu rozwoju kultury.

Podzespół ds. kultury XIII Zespołu Komisji ds. Reformy Gospodarczej opracowywał bardzo ambitną wizję funduszu, który prowadziłby niejako do samofinansowania się kultury: zakładała ona, że dotacje na nierentowną działalność kulturalną pochodziłyby z wpłat (wszelkich podatków) przedsiębiorstw i instytucji wchodzących do „kompleksu gospodarki pracującej na rzecz kultury”, czyli takich, które produkują artykuły użytku kulturalnego i usługi kulturalne [Strąk oprac. 1984: 83-84].

Rozważano też rozwiązanie, w którym fundusz finansowałby tylko koszty zmienne, programowe, gdy koszty stałe - utrzymanie budynku, pensje - pokrywałby organ założycielski. (To właśnie wtedy wchodzi do użytku rozróżnienie, które po dziś jest żywe i niejasno definiowane w dyskusjach o utrzymywaniu instytucji kultury). Już wówczas zrezygnowano $\mathrm{z}$ wariantu finansowania $\mathrm{z}$ wielu źródeł - wtedy instytucje samodzielnie szukałyby mecenasa.

Warto wspomnieć, że w trakcie prac nad projektem, jesienią 1981 roku, wiceminister kultury Józef Puchała stwierdzil, że fundusz „powinien mieć charakter społeczny i powstawać ze świadczeń związków zawodowych i innych organizacji” [BPS/366/ VIII kad. z 29 września 1981: 12]. Wobec postawy organizacji pracowniczych było to jednak nierealne. Można w tym widzieć zabieg retoryczny, korzystny z punktu widzenia rządu, podkreślający paradoks sytuacji, w której związki zawodowe dążą do samorządności, ale nie chcą brać za nic odpowiedzialności. Na innym posiedzeniu sejmowej komisji kultury i sztuki, minister Józef Tejchma nie bez złośliwości zauważył: „Nigdy nie wypowiedziano tyle słów o potrzebie uspołecznienia mecenatu, co w latach 1980-1981 i nigdy równocześnie nie nastąpiło tak gwałtowne wygaśnięcie tego mecenatu" [BPS/509/VIII kad. z 20 kwietnia 1982: 5].

Końcowe prace przypadły już na stan wojenny. Z początkiem roku 1982 koncepcja stworzenia Narodowego Funduszu Rozwoju Kultury wyklarowała się - i to na najwyższym szczeblu - na posiedzeniu Rady Ministrów [BPS/488/VIII kad. z 11 marca 1982: 7]. Środki funduszu powiązano z dynamiką wzrostu płac - wpłaty miały pochodzić $\mathrm{z}$ podatku od wynagrodzeń w gospodarce uspołecznionej (czyli z przedsiębiorstw państwowych). Podstawowymi przesłankami tworzenia NFRK były "narosłe całymi latami, znaczne zaniedbania materialnych podstaw kultury” oraz „rozpad dawnych mecenatów społecznych - związków zawodowych, funduszów socjalnych zakładów pracy i dotacji organizacji spółdzielczych". By naprawić tę sytuację, ustalono, że poziom kwoty wyjściowej NFRK miał: 
stanowić sumę dotychczasowego budżetu Ministerstwa Kultury i Sztuki oraz utraconych środków, jakie płynęły poprzednio z mecenatu związków zawodowych i funduszów socjalnych zakładów pracy. Suma dawnego mecenatu związkowego i socjalnego wyszacowana została na poziomie 2,1 mld zł [BPS/509/VIII kad. z 20 kwietnia 1982: 5].

Wicepremier Mieczysław F. Rakowski dodawał językiem klasycznego marksisty:

Widać, że już pierwsze decyzje ekonomiczne w ramach reformy gospodarczej przynoszą negatywne skutki dla wszystkich sfer nadbudowy, w tym także kultury. (...) Doszliśmy do wniosku, że nie można czekać, że trzeba dążyć do przywrócenia normalnego rytmu sferze kultury [BPS/509/VIII kad. z 20 kwietnia 1982: 15].

Mimo że drugiej kadencji na stanowisku ministra kultury i sztuki Tejchma nie uważał za osobisty sukces, to po latach właśnie w tej ustawie widział „pewien epizod konstruktywny” kierowania resortem w latach 1980-1982. Jak wspominał, Fundusz Rozwoju Kultury to był:

szatański, wspólny pomysł, mój i ministra pracy, prof. Antoniego Rajkiewicza. Uznaliśmy, że w corocznych przetargach o budżet dla kultury, jej minister jest partnerem słabiutkim. Zainicjowaliśmy ustawę sejmową, która przyrost środków na ten cel związała automatycznie z przyrostem płac. (...) W przemówieniu sejmowym zaproponowałem uzasadnienie modelowe: jeśli chcemy przeciwstawić się powstawaniu społeczeństwa wzrostu konsumpcji materialnej ze szkodą dla potrzeb duchowych człowieka, powinniśmy stworzyć mechanizm ustawowy, który nie odda kultury na łaskę technokratów [Tejchma 1996: 129].

4 maja 1982 roku Sejm przyjął Ustawę o Narodowej Radzie Kultury oraz o Funduszu Rozwoju Kultury [Ustawa z dnia 4 maja 1982 r. o Narodowej Radzie Kultury...]. Niemal udało się zdążyć na rocznicę Konstytucji 3 Maja, na czym podobno zależało gen. Wojciechowi Jaruzelskiemu. Nawet na tle innych współczesnych sobie funduszy pozabudżetowych FRK wyróżniał się - miał znacznie większy zakres i rangę, stał się funduszem służącym finansowaniu kultury całościowo: „Kultura i sztuka cieszyła się przywilejem wyjątkowości w podziale finansów publicznych” [Gajewska, Golinowska 1990: 5].

\section{Fundusz Rozwoju Kultury w dzialaniu}

FRK składał się z funduszy: centralnego, wojewódzkich, miejskich, miejsko-gminnych i gminnych. Dochodami funduszu centralnego były: udział w dochodach budżetu państwa w wysokości 13,6\% podatku od płac, dotacje z budżetu państwa, wpłaty ze środków funduszu przeciwalkoholowego w wysokości 15\% rocznych wpływów na 
ten fundusz (co dla niektórych ludzi kultury stało się żartobliwym uzasadnieniem „spożycia”), dobrowolne wpłaty, darowizny, zapisy itp. Środki funduszu przeznaczono na finansowanie twórczości artystycznej oraz działalności instytucji artystycznych, ochronę dóbr kultury, muzealnictwo, biblioteki i rozwój czytelnictwa, kinematografię, funkcjonowanie domów kultury, społeczny ruch kulturalny, na finansowanie utrzymania, budowy i rozbudowy obiektów i urządzeń służących działalności kulturalnej. Funduszem centralnym zarządzał minister kultury i sztuki. Fundusz przewidywał możliwość decentralizacji dodatkowych nakładów finansowych na kulturę, które mogły być rozdzielane przez władze terenowe, lepiej orientujące się w potrzebach instytucji. Fundusz dawał gwarancje stałego dopływu środków na działalność kulturalną.

Efektem stworzenia mechanizmu FRK był skokowy wzrost nakładów na kulturę. W 1983 roku nakłady te stanowiły 1,45\% ogólnych wydatków budżetu państwa wobec 0,96\% w roku 1982 [Kwaśniewska 1987: 157-158]. W kolejnych latach „relatywny wzrost wydatków budżetowych na kulturę i sztukę miał także niebywałe tempo. Jeżeli w roku 1980 - wskaźnik udziału wynosił ok. 1\%, to w roku 1989 - przekroczył 2\%”. W latach 1980-1989 odnotowano przyrost udziału wydatków na kulturę i sztukę w wydatkach budżetowych w wysokości 196\%, a na oświatę i wychowanie 169\% [Gajewska, Golinowska 1990: 3, 5]. Rosły też nakłady inwestycyjne.

Tabela 1. Wydatki na kulturę i sztukę

\begin{tabular}{|l|l|}
\hline \multicolumn{2}{|l|}{ Udział wydatków na kulturę i sztukę w bieżących wydatkach państwa } \\
\hline Rok & Procent \\
\hline 1979 & 1,2 \\
\hline 1980 & 1,1 \\
\hline 1981 & 1,05 \\
\hline 1982 & 1,25 \\
\hline 1983 & 1,85 \\
\hline 1984 & 1,8 \\
\hline 1985 & 1,7 \\
\hline 1986 & 1,63 \\
\hline 1987 & 1,68 \\
\hline 1988 & 1,95 \\
\hline 1989 & 2,16 \\
\hline
\end{tabular}

Źródło: Gajewska, Golinowska 1990: 4.

Jednak ten obraz jest tylko relatywnie dobry. Lata osiemdziesiąte to czas kryzysu - spadał dochód narodowy, stopniowo pogłębiała się stagnacja gospodarcza. 
Zatem rosnące wskaźniki nie oznaczały wcale znaczącej poprawy sytuacji, pozwalały utrzymać kruche status quo. Przykładowo mimo nominalnie znaczącego wzrostu środków na inwestycje w latach osiemdziesiątych ukończono tylko jedną z dużych inwestycji.

Trzeba też podkreślić, że w samej idei funkcjonowania FRK tkwiła słabość. Eugeniusz Żuber podkreślał w swojej analizie, że Fundusz był pomysłem na trudny czas roku 1982 i jednocześnie około roku 1989 podzielał obawy o sytuację FRK „w grach prawnych, finansowo-ekonomicznych, następujących przeobrażeń strukturalnych, gospodarczych i inflacji. Czy ustawowo zapisane niektóre źródła dochodu Funduszu nie będą stawały się martwymi?” [Żuber 1990: 100]. Pytanie to dotyczyło głównego źródła dochodów FRK. Po roku 1984 stopniowo zmniejszał się udział podatku od płac w dochodach budżetu państwa. Rząd reagował na bieżąco, podnosząc procent od tego podatku wpływający na konto Funduszu - w 1987 do 14\%, w 1988 roku do $14,5 \%$. Jednak analizy ekonomiczne dowodziły, że nawet $14,5 \%$ odpisu nie gwarantowało proporcjonalnego i właściwego przyrostu środków.

Mimo zdecentralizowanej struktury, oficjalnie otwartej na nowe inicjatywy, Fundusz służył głównie finansowaniu instytucji i organizacji już wcześniej działających w ramach budżetu państwa:

FRK miał w istocie charakter centralistyczno-administracyjny. Rola administracji rządowej w gospodarowaniu środkami funduszu była niewspółmiernie większa niż społecznej Rady Kultury, a i członkowie Rady Kultury nie pochodzili z wyboru społecznego (powoływani przez premiera) [Gajewska, Golinowska 1990: 3].

Narodowa Rada Kultury niemal automatycznie, bez zastrzeżeń, akceptowała podział środków proponowany przez MKiS.

Ponad $80 \%$ funduszu stanowiły wpływy z podatku od płac; z funduszu przeciwalkoholowego około 1,5\%; wysokie kwoty (ok. 7\%) pochodziły z corocznych nadwyżek budżetowych. Dochody własne udawało się wypracować na poziomie wojewódzkim średnio 4\%. Badaczka polityki kulturalnej, Maria Chełmińska, zwracała uwagę, że FRK:

stanowił formę centralizacji systemu finansowania kultury, pokrywał bowiem niemal całość wydatków w tej dziedzinie. Udział gmin w finansowaniu kultury ze środków publicznych gwałtownie się zmniejszył od początku funkcjonowania FRK: z 55\% w 1982 roku, do zaledwie 6\% w roku 1983 i potem utrzymywał się na zbliżonym poziomie, do 1990 roku włącznie, mieszcząc się w granicach 4\%-10\% [Chełmińska 1993: 87].

Blisko 80\% funduszu szło na finansowanie podmiotowe, czyli na dotacje dla instytucji. Dotacje celowe, przedmiotowe, na realizację konkretnych zadań stanowiły jedynie $4 \%$ wydatków z funduszu. „Dominowała zasada podmiotowego przydzielania 
środków tym instytucjom kultury, które już istniały, miały jakieś lokum, zatrudniały jakąś kadrę i realizowały jakiś program" [Gajewska, Golinowska 1990: 13-14]. Ponadto instytucje i władze wojewódzkie na ogół zawyżały potrzeby finansowe, a wobec braku analiz kosztów niemożliwa była weryfikacja tych postulatów.

Nie wypracowano w miarę obiektywnego systemu dzielenia funduszy:

W procedurze podziału środków miała miejsce tzw. konsultacja. Odpowiednie departamenty Ministerstwa Kultury i Sztuki konsultowały swoje propozycje dotacji z adresatami: przedstawicielami województw oraz instytucjami kultury. (...) Jednakże w procesie negocjacji nie wypracowano podstaw informacyjnych dla uzyskania równych szans partnerów biorących w nim udział [Gajewska, Golinowska 1990: 14].

MKiS nie dysponowało sprawozdaniami instytucji, więc nie dokonywało analizy potrzeb i wydatków. Nie posiadało też:

klarownej koncepcji dotyczącej ilości i kierunków struktury działalności kulturalnej w terenie. Mimo centralistycznej i hierarchicznej struktury układu instytucjonalnego w kulturze ministerstwo w niewielkim stopniu kształtowało nowe proporcje podziału środków. De facto poddane zostało naciskom oddolnym petryfikującym istniejące struktury i układy [Gajewska, Golinowska 1990: 15].

W pierwszych miesiącach funkcjonowania FRK Jerzy Waldorff celnie nazwał problem: „Tak jak w przemyśle obowiązuje zasada trzech «S», tak ministerstwo kultury powinna obowiązywać zasada trzech «K». Decydować ono musi o sprawach koordynacji, kontroli i korekty" [BPS/585/VIII kad. z 23 czerwca 1982: 13]. Ostatecznie nie decydowało. Mimo ambitnych planów uczynienia z MKiS sprawnego i samodzielnego resortu, mimo uchwalenia Ustawy o urzędzie Ministra Kultury i Sztuki [Ustawa z dnia 4 maja 1982 r. o urzędzie...] wszystko zostało po staremu.

W funkcjonowaniu Funduszu uwidoczniły się mankamenty, które obniżają jego osiągnięcia. Po pierwsze, udział społecznego organu programowego, Narodowej Rady Kultury, w kształtowaniu proporcji podziału środków publicznych był ograniczony. Po drugie, nie opracowano koncepcji nowych kryteriów podziału środków funduszu w układzie terytorialnym, instytucjonalnym i branżowym. Po trzecie, zabrakło odpowiedniego obiegu informacji dotyczącej finansowania instytucji kultury i spraw programowych (liczba projektów realizowanych w regionie), „aby procedura negocjowania wielkości dotacji z funduszu dawała większe szanse na słuszną merytorycznie i efektywną dotację środków" [Gajewska, Golinowska 1990: 21]. 


\section{Likwidacja i nowe pomysly}

Minister kultury i sztuki w rządzie Tadeusza Mazowieckiego, Izabella Cywińska, w maju 1990 roku na posiedzeniu sejmowej Komisji Kultury i Sztuki poinformowała o pomyśle likwidacji i - wobec jeszcze wtedy braku decyzji rządowej - zaapelowała:

aby lobby kulturalne zajęło się obroną Funduszu Rozwoju Kultury. Konieczne jest utrzymanie takiej formuły finansowania kultury, która pozwoliłaby na elastyczne dysponowanie środkami materialnymi przez Ministerstwo Kultury i Sztuki [BPS/475/X kad. z 30 maja 1990: 39].

Pomysł likwidacji FRK był częścią szerszego planu ministra finansów, Leszka Balcerowicza. W 1989 roku funkcjonowało 38 funduszy pozabudżetowych. W roku 1989 27\% przychodów Funduszu stanowiła dotacja z budżetu państwa. Pod koniec tego roku doszło też do paradoksalnej sytuacji - budżet państwa miał 3,6 bln zł deficytu, a fundusze 2 bln niewykorzystanych środków. Likwidacja funduszy była jednym z elementów reformy finansów publicznych i docelowo miała uporządkować gospodarkę budżetową przez włączenie do budżetu zadań, dochodów i wydatków realizowanych za pośrednictwem pozabudżetowych funduszów celowych. Takie rozwiązanie umożliwiało też lepszą kontrolę nad wydatkami. Cytowany tu raport Julii Gajewskiej i Stanisławy Golinowskiej powstał w lipcu 1990 roku w kontekście projektów likwidacji FRK. I właściwie był jedyną gruntowną analizą działania Funduszu.

Nikt aktywnie nie bronił Funduszu. Zwłaszcza że rząd zapewniał o utrzymaniu finansowania kultury na możliwie niezmiennym poziomie. 4 grudnia 1990 roku Sejm uchwalił Ustawę o zniesieniu i likwidacji niektórych funduszy [Dz.U. $1990 \mathrm{nr} 89$ poz. 517] i tym samym zlikwidował 16 rozmaitych funduszy, między innymi Fundusz Kinematografii, terenowe fundusze odnowy zabytków, Centralny Fundusz Turystyki i Wypoczynku, Centralny Fundusz Rozwoju Kultury Fizycznej, Fundusz Zapobiegania Narkomanii, Fundusz Gospodarki Mieszkaniowej i Fundusz Gospodarki Gruntami, Państwowy Fundusz Młodzieży, Fundusz Nasiennictwa, Fundusz Rozwoju Budownictwa Mieszkaniowego, Fundusz Rozwoju Eksportu, Fundusz Socjalny Wsi, Centralny Fundusz Rozwoju Nauki i Techniki.

W wypadku środków z FRK udało się zachować środki na rzecz kultury. Cywińska postanowiła odejść z rządu wraz z Mazowieckim: „Na odchodnym udało mi się jeszcze załatwić u prof. Leszka Balcerowicza, że pieniądze z Funduszu Rozwoju Kultury nie będą automatycznie wchłonięte przez budżet państwa, tylko zostaną oddane Fundacji Kultury" [Gawiński 2011]. Blisko 117 mld zł trafiło na konto Fundacji, której prezeską została Cywińska. Wśród założycieli Fundacji powołanej do życia 11 czerwca 1990 roku znaleźli się senator Aleksander Gawronik, wiceminister Michał Jagiełło, Mieczysław Wilczek (minister przemysłu w rządzie Rakowskiego). W 1994 roku sprawa zakończyła się skandalem. NIK skierował do prokuratury wniosek o wszczęcie postępowania karnego wobec Fundacji pod zarzutem niegospodarnego 
rozporządzania funduszami publicznymi. Środki Fundacji zostały zaangażowane w rozmaite działania biznesowe, które zamiast przynosić zyski przyniosły poważne straty [Kuczyńska 1994].

Pomysł na fundusz pozabudżetowy niespodziewanie szybko powrócił. W 1993 ministrem kultury i sztuki w rządzie SLD-PSL został wybitny reżyser i dyrektor teatrów Kazimierz Dejmek. Jego pierwszym pomysłem było stworzenie Funduszu Rozwoju Kultury - oczywiście na nowych zasadach pozyskiwania środków, na przykład z produkcji materialnych dóbr kultury, takich jak kasety, płyty, telewizory. Podstawową ambicją Dejmka było uniezależnienie środków na kulturę od resortu finansów:

Nie zgadzam się tylko z tym, by o nakładach na kulturę decydowali specjaliści, nawet najlepsi, z Ministerstwa Finansów, bo jednak uważam, że pracownicy MKiS potrafią to zrobić lepiej. Życie kulturalne nie kończy się w noc sylwestrową, tak jak ma to miejsce $\mathrm{z}$ wydatkami budżetowymi [Dejmek, Lutomski 1993].

Minister Dejmek dodatkowo przypomniał, że powołanie FRK to „jedna z wielkich decyzji gen. Jaruzelskiego, ale to nie był jego wynalazek, bo taki fundusz istniał już przed wojną". Można uznać tę wypowiedź za zgrabny paradoks (tu sanacja, tu komuniści, a pomysł podobny) lub za kontrowersyjne stwierdzenie - z powodu komplementu dla generała. Niemniej konieczne jest tu pewne wyjaśnienie. Fundusz Kultury Narodowej utworzony w 1928 roku - z inicjatywy marszałka Józefa Piłsudskiego - finansował stypendia naukowe i artystyczne, gdyż uważano, „że podstawą i motorem wszelkiej twórczej pracy jest jednostka”; a zatem Fundusz „starał się przede wszystkim przygotować do pracy twórczej jak najwięcej uzdolnionych jednostek" [Płoski 2018: 505]. Fundusz działał akcyjnie i bez długofalowego planu. Stabilizacji nie sprzyjał nieustannie zmniejszany budżet. W latach 1928-1936 cała dotacja na naukę wynosiła 9,5 mln złotych, a na sztukę - około $4 \mathrm{mln}$ zł. Tak więc na sztukę (w tym teatr) w tym okresie wydatkowano przeciętnie rocznie około 500 tys. zł [Soroka 1995: 115]. Nawet prestiżowa zmiana nazwy FKN na Instytut Kultury Narodowej im. Józefa Piłsudskiego nie pomogła w zwiększeniu nakładów finansowych. Szef Instytutu, Stanisław Michalski, pisał, „że nauka i sztuka polska znajduje się w warunkach umożliwiających właściwie tylko wegetację, nie zaś normalny rozwój i rozrost" [Żółkiewski 1973: 80]. Przedwojenny Fundusz Kultury Narodowej był zatem drobiazgiem bez znaczenia w wydatkach Drugiej Rzeczpospolitej wobec konstrukcji FRK.

Dejmkowi nie udało się zrealizować swojego zamiaru. Ale pomysł na pozabudżetowe finansowanie kultury nie przepadł. Według takich zasad finansowania powołano Polski Instytut Sztuki Filmowej, który okazał się wielkim sukcesem i doprowadził do poprawy sytuacji polskiej kinematografii [Majer, Orankiewicz, Wróblewska 2019]. Zainspirowany tym rozwiązaniem Maciej Nowak, ówczesny 
dyrektor Instytutu Teatralnego, wraz z zespołem ekspertów - przy okazji Kongresu Kultury Polskiej w 2009 roku - postulował stworzenie dodatkowych mechanizmów pozabudżetowego finansowania kultury wzorowanego na rynku rolnym:

\begin{abstract}
Niezbędne jest znalezienie sposobu na powiększenie zasobów kultury za pośrednictwem mechanizmu pozabudżetowego, który zasilałby Fundusz Promocji Kultury, np.: poprzez opłaty od alkoholu, papierosów, imprez masowych, reklamy, turystyki, itp. Analogię może tutaj tworzyć np. Ustawa z dnia 22 maja 2009 roku o funduszach promocji produktów rolno-spożywczych, zgodnie z którą nabywca produktów rolnych winien uiszczać do Agencji Rynku Rolnego opłatę w wysokości $0,1 \%$ od wartości netto nabytych warzyw i owoców, zbóż czy mięsa. Pomysłem na uzupełnienie źródeł finansowania Funduszu Promocji Kultury, mogłoby być pobieranie od organizatorów wszelkiego rodzaju imprez rozrywkowych określonego procentu od kwoty netto ze sprzedaży wstępu (bilety, faktury) na te imprezy. Zgromadzone w ten sposób środki powinny służyć zdynamizowaniu pracy instytucji kultury oraz aktywnym formom uprawiania polityki kulturalnej [Trzy kroki ku zmianom na lepsze w polskiej kulturze 2009: 22-23].
\end{abstract}

Od 2017 roku w MKiDN trwają prace nad stworzeniem Funduszu Wsparcia Artystów Zawodowych, finansującego składki ubezpieczeń społecznych artystów, dla którego źródłem przychodów miałyby być środki z tytułu opłaty, o której mowa $\mathrm{w}$ art. 20 ustawy z o prawie autorskim i prawach pokrewnych [Ustawa z 4 lutego 1994 r. o prawie autorskim...]. W projekcie nowelizacji byłyby to opłaty ze sprzedaży urządzeń reprograficznych, magnetowidów i innych podobnych urządzeń oraz związanych z nimi czystych nośników, a także komputerów, tabletów, telefonów, telewizorów $\mathrm{z}$ funkcją smart-TV.

\title{
Podsumowanie
}

Profesor Dorota Ilczuk wspominała, że w latach osiemdziesiątych podczas odbywających się w Europie Zachodniej konferencji, pytano ją o Fundusz Rozwoju Kultury: jak to możliwie, że w Polsce wprowadzono tak rewelacyjny sposób finansowania kultury. - To proste - odpowiadała ironicznie. - Wystarczy wprowadzić stan wyjątkowy. Losy kolejnych inicjatyw - przede wszystkim PISF - pokazały, że w ostatnich dekadach splot okoliczności bywa szczęśliwszy niż w przytoczonej wyżej anegdocie.

FRK był niewątpliwie osiągnięciem w kontekście trudności finansowych państwa $\mathrm{w}$ drugiej połowie lat osiemdziesiątych. $\mathrm{Z}$ tego powodu wydaje się, że można traktować powstanie FRK jako - cytując ministra Tejchmę - epizod konstruktywny, który ochronił kulturę przed ekonomizacją i komercjalizacją w czasie, gdy ekipa Jaruzelskiego opracowywała coraz głębsze reformy gospodarcze.

Pierwotne idee twórców założeń ustawy o FRK pozostały w sferze marzeń. Fundusz nie zmienił struktury podziału środków na kulturę, raczej petryfikował 
ją. Władze - od centralnych po lokalne - nie były zainteresowane zmianą, choć ustawa dawała możliwości konstruowania nowych zasad. Najpierw należało znaleźć środki na dotychczas działające instytucje. Nikt nie miał zamiaru weryfikować ich działań i ich kosztów.

Co jednak warto podkreślić - w wyniku przemian roku 1989 - też nie powstał pomysł zasadniczo zmieniający reguły gry. Jeśli sięgnie się po opracowania dotyczące reformy gospodarczej w kulturze [Strąk oprac. 1984], to z zaskoczeniem można zauważyć, że powstało tam wiele koncepcji, które doskonale pasowały do nowego kapitalistycznego i demokratycznego ustroju - były tam propozycje rozwiązań, które mogły zdecydowanie poluzować organizacyjny gorset. Można już tylko snuć przypuszczenia, czy utrzymanie FRK mogłoby doprowadzić do stworzenia polskiej wersji Arts Council, a co za tym idzie - do nowego ładu instytucjonalnego.

\section{Bibliografia}

\section{Opracowania}

Bieniewski H. (1987), Problemy instytucji artystycznych a reforma gospodarcza, [w:] B. Sicińska (red.), Reforma gospodarcza w kulturze (materialy i opracowania z okresu prac nad koncepcja), Warszawa: Instytut Kultury, s. 140-154.

BPS/366/VIII kad. z 29 września 1981, Sejm PRL, kadencja VIII, Biuletyn Komisji Kultury i Sztuki. BPS/475/X kad. z 30 maja 1990 Sejm PRL / Sejm RP, kadencja X, Biuletyn Komisji Kultury i Środków Przekazu.

BPS/488/VIII kad. z 11 marca 1982, Sejm PRL, kadencja VIII, Biuletyn Komisji Kultury i Sztuki. BPS/509/VIII kad. z 20 kwietnia 1982, Sejm PRL, kadencja VIII, Biuletyn Komisji Kultury i Sztuki. BPS/585/VIII kad. z 23 czerwca 1982, Sejm PRL, kadencja VIII, Biuletyn Komisji Kultury i Sztuki. Chełmińska M. (1993), Warunki rozwoju kultury na szczeblu lokalnym. Europejskie modele rozwiazań systemowych a sytuacja w Polsce, Warszawa: Instytut Kultury.

Dejmek K., Lutomski J. (1993), Ja nie jestem dolar. Rozmowa Jacka Lutomskiego z Kazimierzem Dejmkiem, ministrem kultury i sztuki, „Rzeczpospolita”, nr 268.

Dudek A. (2004), Reglamentowana rewolucja. Rozkład dyktatury komunistycznej w Polsce 1988-1990, Kraków: Arcana.

Gajewska J., Golinowska S. (1990), Raport o funkcjonowaniu Funduszu Rozwoju Kultury w latach 1983-1990. Wnioski na tle projektu likwidacji FRK, Warszawa: Instytut Kultury.

Gawiński T. (2011), Bogata przyszłość, „Angora”, nr 29.

Jarmułowicz M. (2003), Sezony błędów i wypaczeń. Socrealizm w dramacie i teatrze polskim, Gdańsk: Wydawnictwo Uniwersytetu Gdańskiego.

Kowal P. (2012), Koniec systemu władzy. Polityka ekipy gen. Wojciecha Jaruzelskiego w latach 1986-1989, Warszawa: Instytut Studiów Politycznych PAN, Instytut Pamięci Narodowej, Wydawnictwo Trio. 
Kuczyńska T. (1994), Jestem kompetentna, „Tygodnik Solidarność”, nr 42.

Kwaśniewska K. (1987), Wybrane zagadnienia ekonomiki kultury, Warszawa: Centralny Ośrodek Metodyki i Upowszechniania Kultury.

Lachowski M. (2006), Awangarda wobec instytucji. O sposobach prezentacji sztuki w PRL-u, Lublin: Towarzystwo Naukowe KUL.

Leszczyński A. (2013), Skok w nowoczesność. Polityka wzrostu w krajach peryferyjnych 1943-1980, Warszawa: ISP PAN - Wydawnictwo Krytyki Politycznej.

Majer A., Orankiewicz A., Wróblewska A. (2019), Pieniądze - produkcja - rynek. Finansowanie produkcji filmowej w Polsce, Łódź: PWSFTviT.

Napiontkowa M. (2012), Teatr polskiego Października, Warszawa: Instytut Sztuki PAN.

Płoski P. (2018), W poczekalni. Sprawy teatru w polityce kulturalnej II RP, [w:] B. Osterloff (red.), Ryszard Bolesławski. Jego twórczość i jego czasy / Richard Boleslavsky: His Work and His Times, Warszawa: Akademia Teatralna im. Aleksandra Zelwerowicza.

Protokół porozumienia zawartego pomiędzy Komisją Rządową a Komitetem Strajkowym Pracowników Kultury NSZZ „Solidarność”, z 17 XI 1980, sygn. A/16.07.05 (1980), Archiwum Ośrodka Karta - Biblioteka Cyfrowa Ośrodka Karta, teczka Strajk solidarnościowy pracowników służby zdrowia, oświaty i kultury w Gdańsku w listopadzie 1980 roku.

Rosenberg M. (2016), Działalność sekcji branżowych NSZZ „Solidarność” w latach 1980-1981 na przykładzie Krajowej Komisji Porozumiewawczej NSZZ „Solidarnośc” Pracowników Teatru, „Polska 1944/45-1989”, nr 14.

Rozporządzenie Rady Ministrów z dnia 2 listopada 1973 r. w sprawie zakładowego funduszu socjalnego i zakładowej działalności socjalnej (1973), Dz.U. 1973 nr 43 poz. 260.

Soroka J.M. (1995), Polska Partia Socjalistyczna wobec problemów kulturalno-oświatowych 1918-1939, Wrocław: Wydawnictwo Akademii Ekonomicznej.

Sowa A.L. (2011), Historia polityczna Polski 1944-1991, Kraków: Wydawnictwo Literackie.

Stano B. (2019), Artysta w fabryce. Dwa oblicza mecenatu przemysłowego w PRL, Kraków: Uniwersytet Pedagogiczny w Krakowie.

Strąk M. (1983), Bronię drugiego układu, Warszawa: Ludowa Spółdzielnia Wydawnicza.

Strąk M. (1984), oprac., Kultura. Polska reforma gospodarcza, Warszawa: Państwowe Wydawnictwo Ekonomiczne.

Szczutkowska J. (2014), Polityka kulturalna PRL w dziedzinie kinematografii w latach 70., Bydgoszcz: Wydawnictwo Uniwersytetu Kazimierza Wielkiego.

Tejchma J. (1996), Pożegnanie z władza, Warszawa: Wydawnictwo „Projekt”.

Ustawa z dnia 25 września 1981 r. o przedsiębiorstwach państwowych (1981), Dz.U. 1981 nr 24 poz. 122.

Ustawa z dnia 4 maja 1982 r. o Narodowej Radzie Kultury oraz o Funduszu Rozwoju Kultury (1982), Dz.U. 1982 nr 14 poz. 112.

Ustawa z dnia 4 maja 1982 r. o urzędzie Ministra Kultury i Sztuki (1982), Dz.U. 1982 nr 14 poz. 112.

Ustawa z dnia 4 grudnia 1990 r. o zniesieniu i likwidacji niektórych funduszy (1990), Dz.U. 1990 nr 89 poz. 517. 
Ustawa z 4 lutego 1994 r. o prawie autorskim i prawach pokrewnych (1994), Dz.U. 1994 nr 24 poz. 83 (tekst jednolity: Dz.U. 2019 poz. 1231).

Wallis A. (1981), Problemy centralizacji i decentralizacji życia kulturalnego w Polsce $w$ latach 1945-1980, Warszawa: Instytut Kultury - Ośrodek Informacji Naukowej i Statystyki Kulturalnej.

Zajiček E. (2009), Poza ekranem. Kinematografia polska 1896-2005, Warszawa: SFP, Studio Filmowe Montevideo.

Żółkiewski S. (1973), Kultura literacka 1918-1932, Wrocław: Ossolineum.

Żuber E. (1990), Finansowanie kultury, Koszalin: Koszalińskie Towarzystwo Społeczno-Kulturalne i Koszaliński Ośrodek Naukowo-Badawczy.

\section{Netografia}

Śliwonik L., Uniejewska E. (2014), Przekroczył zwyczajność - życia i teatru. Z Lechem Śliwonikiem rozmawia Ewa Uniejewska, http://teatralny.pl/rozmowy/przekroczyl-zwyczajnosc-zycia -i-teatru,301.html [odczyt: 20.10.2019].

Trzy kroki ku zmianom na lepsze w polskiej kulturze (2009), Warszawa: Instytut Teatralny im. Zbigniewa Raszewskiego, http://www.kongreskultury.pl/library/File/Trzy\%20kroki\%20 ku\%20zmianom\%20na\%20lepsze\%20w\%20polskiej\%20kulturze.pdf [odczyt: 26.10.2019]. 